\title{
WATER RESOURCES ACTIVITIES OF THE MISSISSIPPI DISTRICT, 1990-91
}

By Carol P. Moss

U.S. GEOLOGICAL SURVEY

Open-File Report 91-234

Jackson, Mississippi 1991 


\section{U.S. DEPARTMENT OF THE INTERIOR \\ MANUEL LUJAN, JR., Secretary}

U.S. GEOLOGICAL SURVEY

Dallas, L. Peck, Director

For additional information write to:

District Chief

U.S. Geological Survey

Suite 710, Federal Building $100 \mathrm{~W}$. Capitol Street

Jackson, Mississippi 39269
Copies of this report can be purchased from:

U.S. Geological Survey Books and Open-File Reports Section Building 810 Box 25425, Federal Center Denver, Colorado 80225 


\section{CONTENTS}

Page

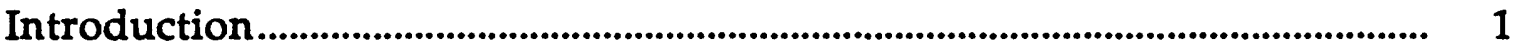

Surface-water data collection............................................................................ 3

Ground-water data collection................................................................................ 4

Quality-of-water data collection............................................................................ 5

Sediment data collection................................................................................................... 6

Acid-precipitation data collection ...................................................................... 7

Water-use information ................................................................................................... 8

Collection and analysis of flood data ............................................................... 9

Hydrologic monitoring in the area of the Tennessee-Tombigbee

Waterway ............................................................................................................... 10

Potentiometric mapping .............................................................................................. 11

Low-flow characteristics of Mississippi streams.................................................... 12

Ground-water flow analysis of the Cockfield Formation and the

Sparta Sand in the three-county, Jackson, Mississippi, Metropolitan

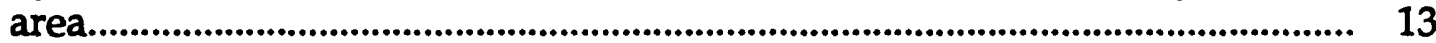

Magnitude and frequency of floods in Mississippi.............................................. 14

Analysis of aquifer-test data......................................................................................... 15

Channel adjustment processes, bank-slope development, and long-

term channel geometry in selected reaches of Mississippi streams ......... 16

Ground-water resources of northeastern Mississippi......................................... 17

Geohydrology and simulated effects of ground-water withdrawals on the Miocene aquifer in selected areas of southern Mississippi ................. 18

Bridge-scour prediction equations for Mississippi streams................................ 19

Development of a methodology to better estimate channel meandering

Susceptibility of major aquifers in Mississippi to surface and shallowsource contamination.

Determination of methods for characterization of underground injection sites in Mississippi................................................................................. 22

Mississippi District reports published since 1989................................................ 23 


\title{
WATER RESOURCES ACTIVITIES OF THE MISSISSIPPI DISTRICT, 1990-91
}

\author{
By Carol P. Moss
}

\section{Introduction}

This report describes the activities and programs of the U.S. Geological Survey, Water Resources Division, in Mississippi during 1990-91. The work of the Mississippi District is accomplished, in large part, through cooperation with local, State, and other Federal agencies who share in the planning and financial support of the program. The annual budget for the Mississippi District in 1991 is more than 3.2 million dollars.

The principal mission of the Mississippi District is to investigate the occurrence, quantity, quality, distribution, and movement of surface and ground water in the State. To accomplish this mission, the Mississippi District employs about 50 professional, technical, and support personnel. Hydrologic data-collection programs and interpretative studies are conducted by the Hydrologic Data Section and the Hydrologic Investigations Section. These sections are responsible for implementation and execution of District projects. The Administrative Services Section, the Computer Applications Unit, and the Reports Preparation Unit provide support services to all District personnel.

Results of most data-collection programs and interpretative studies conducted by the Mississippi District are published in U.S. Geological Survey reports or outside publications and are made available to universities, State and local agencies, other Federal agencies, and to the public. A list of reports published since 1989 is included in this report; these reports are available for inspection at the District Office in Jackson.

Local, State, and other Federal agencies that provided funding and services in support of water-resources investigations in Mississippi during 1990-91 include: 
- City of Jackson

- Harrison County Board of Supervisors

- Harrison County Development Commission

- Jackson County Board of Supervisors

- Jackson County Port Authority

- Mississippi Department of Agriculture and Commerce

- Mississippi Office of Geology

- Mississippi Office of Land and Water Resources

- Mississippi Office of Pollution Control

- Mississippi State Highway Department

- National Aeronautics and Space Administration

- Pat Harrison Waterway District

- Pearl River Basin Development District

- Pearl River Valley Water Supply District

- Tombigbee River Valley Water Management District

- U.S. Army Corps of Engineers

- U.S. Soil Conservation Service

- Yazoo-Mississippi Delta Joint Water Management District 


\section{SURFACE-WATER DATA COLLECTION}

Surface-water information is needed for purposes of surveillance, planning, design, hazard warning, operation, and management in water-related fields such as water-supply, hydroelectric-power generation, flood control, irrigation, bridge and culvert design, wildlife management; pollution abatement, flood-plain management, and water-resources development. To provide this information, an appropriate data base is necessary. The Mississippi District surface-water program is conducted in cooperation with many local, State, and other Federal agencies with the following objectives:

- Collect information on the surface-water resources of the State of Mississippi.

- Store this information in computerized local and national water-resources data bases.

- Disseminate surface-water information to local, State, and other Federal agencies, as well as to educational institutions, private organizations, and the public by means of an annual report and direct responses to individual requests.

During 1990, data were collected at more than 60 continuous-record streamflow sites and at more than 80 partial-record sites.

M.L. Plunkett directs the surface-water data-collection program in Mississippi.

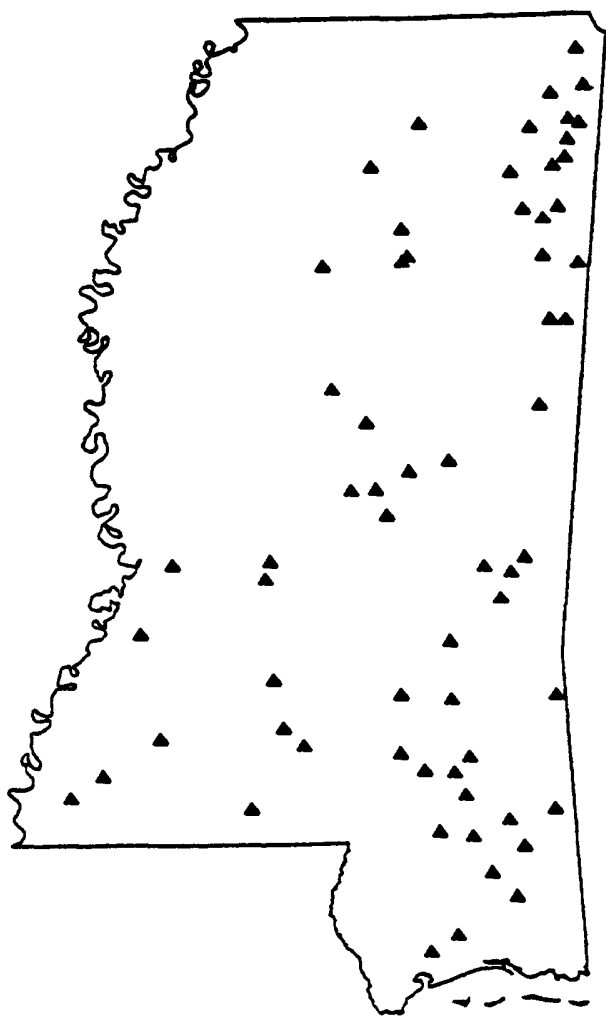

Locations of continuous-record streamflow sites 


\section{GROUND-WATER DATA COLLECTION}

Long-term water-level records are needed: to evaluate the effects of climatic variations on the recharge to and discharge from the major aquifers in the State; to provide a data base from which to measure the effects of development on future supplies; and to provide data for management of the water resources. The Mississippi District ground-water data-collection program is conducted in cooperation with State and local agencies with the following objectives:

- To collect sufficient water-level data to provide a long-term data base so that the general response of the ground-water system to natural climatic variations and induced stresses is known.

- To aid in the early identification of potential problems that might threaten the ground-water resource.

- To aid in the proper management of the ground-water resource.

- To provide a data base against which the short-term record acquired in areal studies can be analyzed. This analysis must 1) provide an assessment of the ground-water resource; 2 ) allow estimates of future conditions; 3 ) detect and define contamination and supply problems; and 4) provide the data base necessary for management of the ground-water resource.

During 1990, water-level measurements were made at 240 observation wells in the statewide network, and continuous recorders were operated on about 30 wells. Water-quality samples were collected from 37 wells, and data from 37 geophysical logs were compiled. Data on about 150 new water wells were added to the GroundWater Site Inventory (GWSI) file, increasing the total sites in the file to 64,790 .

The principal investigator for this project is William T. Oakley.

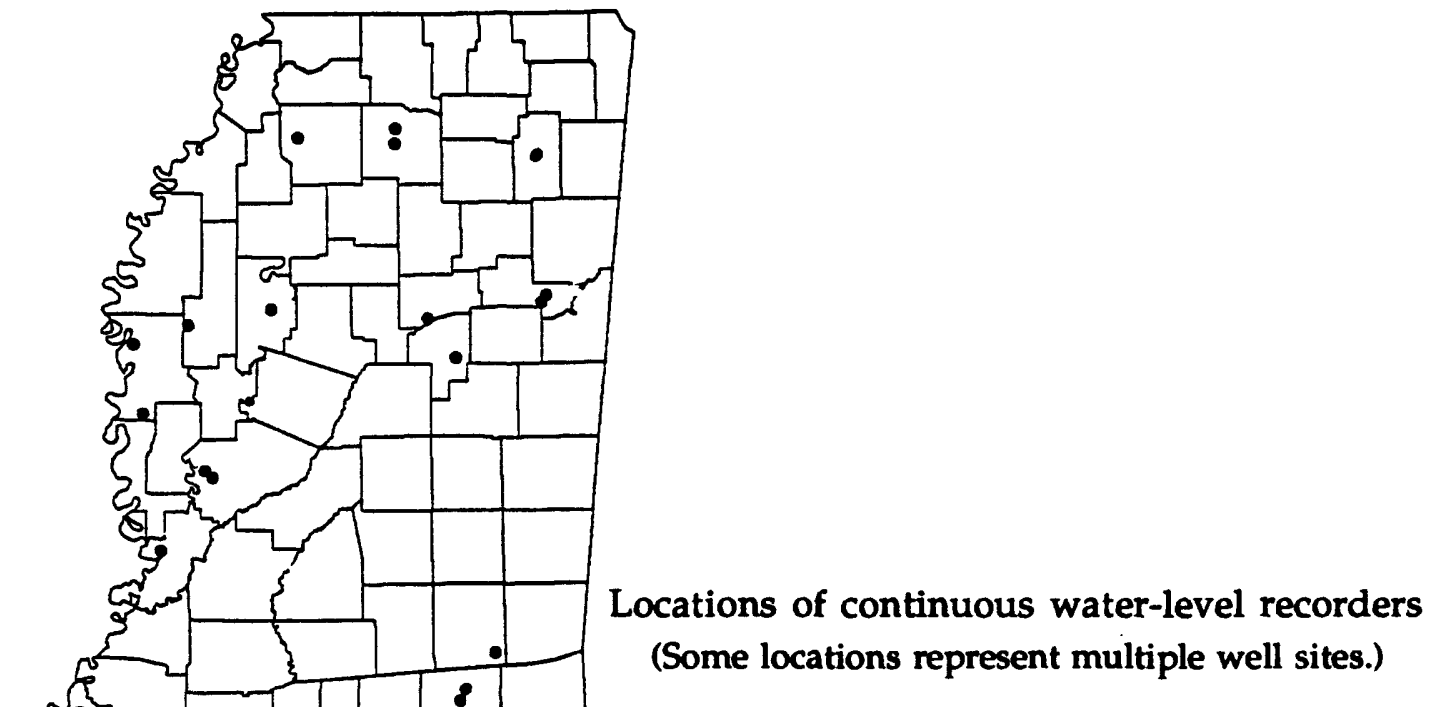




\section{QUALITY-OF-WATER DATA COLLECTION}

Water-resource planning and water-quality assessment require a nationwide base level of relatively standardized information. For intelligent planning and realistic assessment of the water resource, the chemical and physical quality of surface and ground water must be defined and monitored.

To obtain and document an unbiased inventory of water-quality data for use in the planning and development of the water resources of the State of Mississippi, one or more water-quality samples were collected at 112 surface-water sites and at 37 ground-water sites in 1990.

- Water-quality data were collected at six National Stream Quality Accounting Network (NASQAN) stations and at one Hydrologic Benchmark (HBM) station.

- Water-quality data were collected over a tide cycle in a Gulf Coast estuary.

- A water-quality monitor was operated on the Mississippi River.

Hydrologist Larry J. Slack, District Water-Quality Specialist, is the principal investigator for the quality-of-water data-collection program.

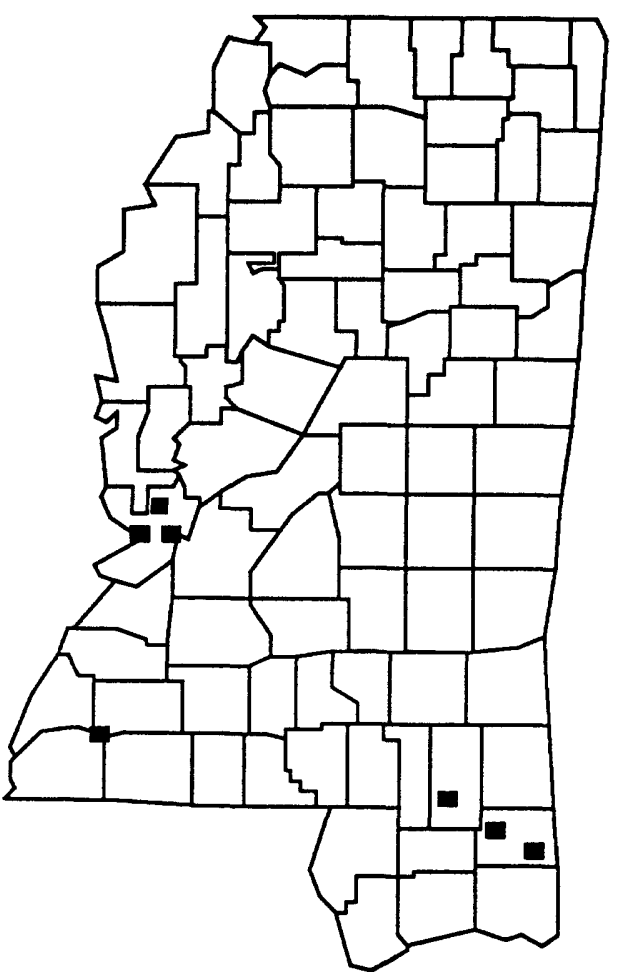

NASQAN and HBM stations in Mississippi 


\section{SEDIMENT DATA COLLECTION}

Sediment concentrations in rivers and streams must be defined and monitored to provide information for water-resource planning and water-quality assessment. The Mississippi District sediment program is conducted in cooperation with other Federal agencies with the following objectives:

- Provide sediment data for use in Federal and State planning and action programs.

- Provide sediment data for Federal management of interstate and international waters.

During 1990, water-discharge data were collected at 10 daily discharge sites as part of the sediment data-collection program. Bed-material samples and daily suspended-sediment data were collected at six of these sites. Discharge and suspended-sediment data were collected at 13 routine stations on regularly scheduled visits at 6-week intervals. Data collected at all sites were published in the annual data report. George.

Project chief of the sediment data-collection program in Mississippi is Fred

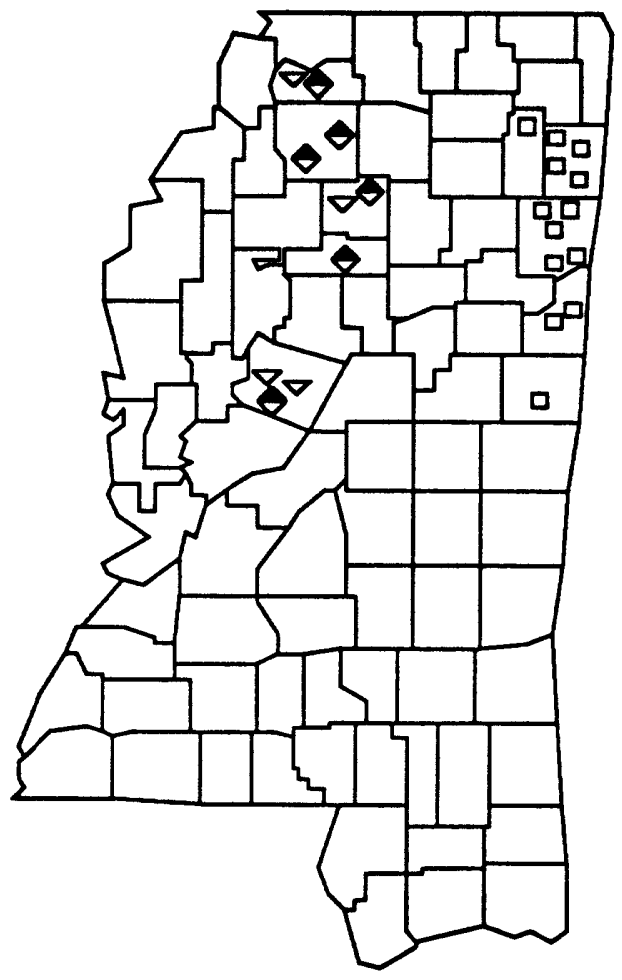

\section{EXPLANATION}

Daily - sediment sites

Daily - discharge sites

- Routine sites 


\section{ACID-PRECIPITATION DATA COLLECTION}

Since 1982 the U.S. Geological Survey has conducted a program to monitor the quality of precipitation in Mississippi. Currently, the USGS, in cooperation with other Federal agencies and the Mississippi Office of Pollution Control, collects longterm data required to assess the effect that selected inorganic chemical constituents and physical properties of atmospheric precipitation may have on the environment. The purposes of the program are:

- To monitor and (or) analyze atmospheric precipitation at six stations.

- To store the data that are collected in a computerized data base.

- To evaluate water-quality trends in streams and lakes in the State (as related to atmospheric precipitation).

Methods for the collection and analysis of samples are comparable to those of the National Trends Network. Paul E. Grantham is project chief of the acidprecipitation data-collection program in Mississippi.

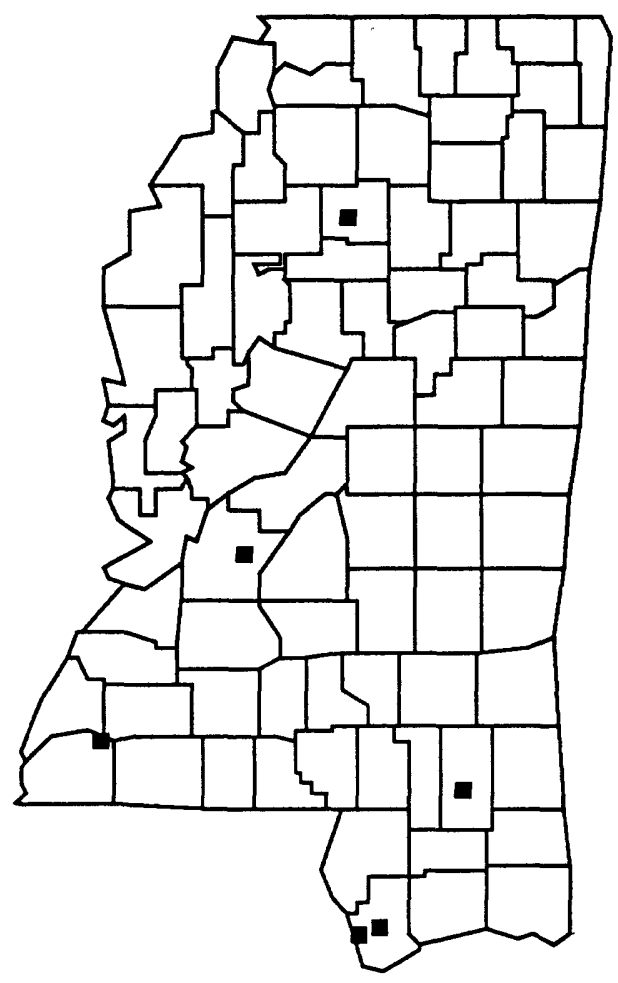

General location of precipitation-quality stations in Mississippi 


\section{WATER-USE INFORMATION}

The demand for water in Mississippi continues to increase because of increasing water requirements of public suppliers, industries, irrigators, and catfish farmers. Water managers need a consistent and accurate record of water use to be able to predict future needs and ensure that those needs can be met. The Mississippi District water-use program is conducted in cooperation with the Mississippi Office of Land and Water Resources and the Yazoo-Mississippi Delta Joint Water Management District with the following objectives:

- Collect information on the amount of surface and ground water withdrawn by major water users.

- Store this information in a computerized data base.

- Disseminate water-use information to the public by means of reports and presentations, and provide water-use data as needed for other District projects.

During 1990, work focused on cross-checking and correcting the Mississippi water-use data base in preparation for the 1990 compilation of "Estimated Use of Water in the United States." In addition, time-totalizers were maintained on 25 public-supply and industrial wells in the coastal area.

Hydrologist Nancy L. Barber served as the principal investigator for the Mississippi water-use program in fiscal year 1990 and was replaced by Penny J. Hom during fiscal year 1991.

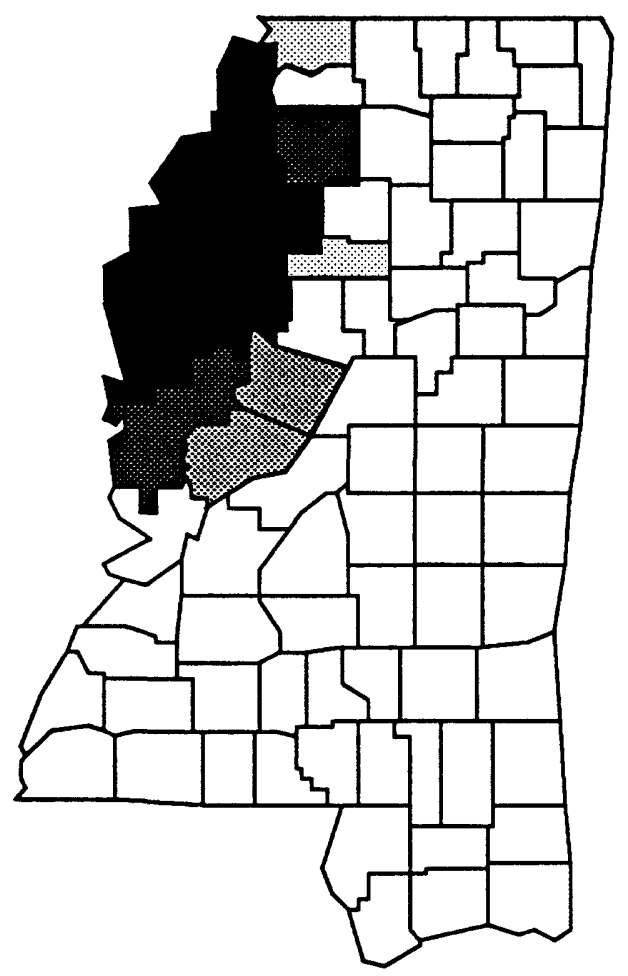

\section{EXPLANATION}

Withdrawals, in million gallons per day

$\square \leq 2$

$>2-4$

$>4-10$

$>10-40$

$>40-400$

Irrigation withdrawals, 1985, by county 


\section{COLLECTION AND ANALYSIS OF FLOOD DATA}

The Mississippi State Highway Department annually spends millions of dollars for highway construction. Streamflow records, hydrologic analyses of basins, and hydraulic analyses of the flooding potential at proposed crossings are necessary for economical and optimum designs of highway-drainage structures. The studies have the following objectives:

- To evaluate and analyze the flooding potential at highway crossings of streams throughout Mississippi using existing hydrologic and hydraulic data.

- To systematically analyze flood data and prepare reports presenting the flood data.

Flood-frequency characteristics and hydraulic characteristics at a highway crossing are determined from historical flood elevations recovered by the U.S. Geological Survey, cross-section data, and correlations with nearby gaged stations. The flood information collected in these studies not only provides the basis for the design of highways and drainage structures, but also is used by local agencies and the general public as a guide in flood-plain management.

In fiscal year 1990, hydrologic and hydraulic analyses of streams at highway crossings at about 90 sites in Mississippi were prepared. About 50 requests for flood information are answered each year.

The chief of this project is James W. Hudson.

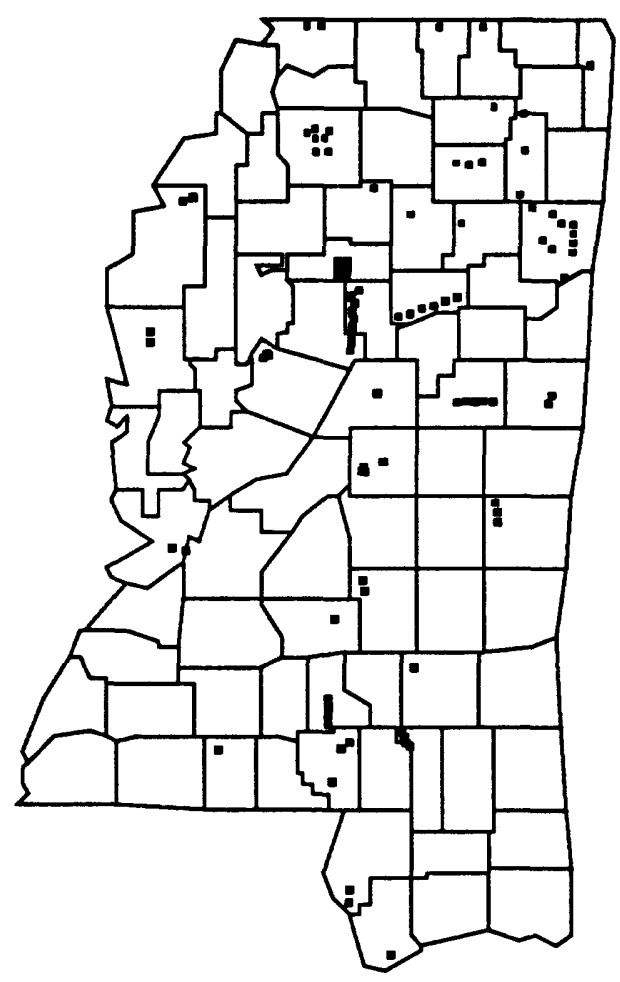

Flood-study sites, 1990 


\section{HYDROLOGIC MONITORING IN THE AREA OF THE TENNESSEE-TOMBIGBEE WATERWAY}

Hydrologic data are needed to monitor the effect of the construction and operation of the Tennessee-Tombigbee Waterway on the quality of surface and ground water, streamflow characteristics, and ground-water levels in the area. The monitoring project, which began in 1971, was conducted in cooperation with the U.S. Army Corps of Engineers. The objectives of this multi-year project were to:

- Collect data descriptive of the pre-construction hydrologic system of the area.

- Monitor the potential changes in the hydrologic system during the construction of the Tennessee-Tombigbee Waterway.

- Monitor the hydrologic system during operation of the Waterway.

During 1990, ground-water levels were monitored in 134 observation wells and streamflow data were collected at 15 sites. Water-quality samples were collected at 5 ground-water and 15 surface-water sites. Data collected during water years 1987 through 1990 are being prepared for publication. The project was discontinued at the end of the 1990 fiscal year.

Fred Morris III is the principal investigator for this project.

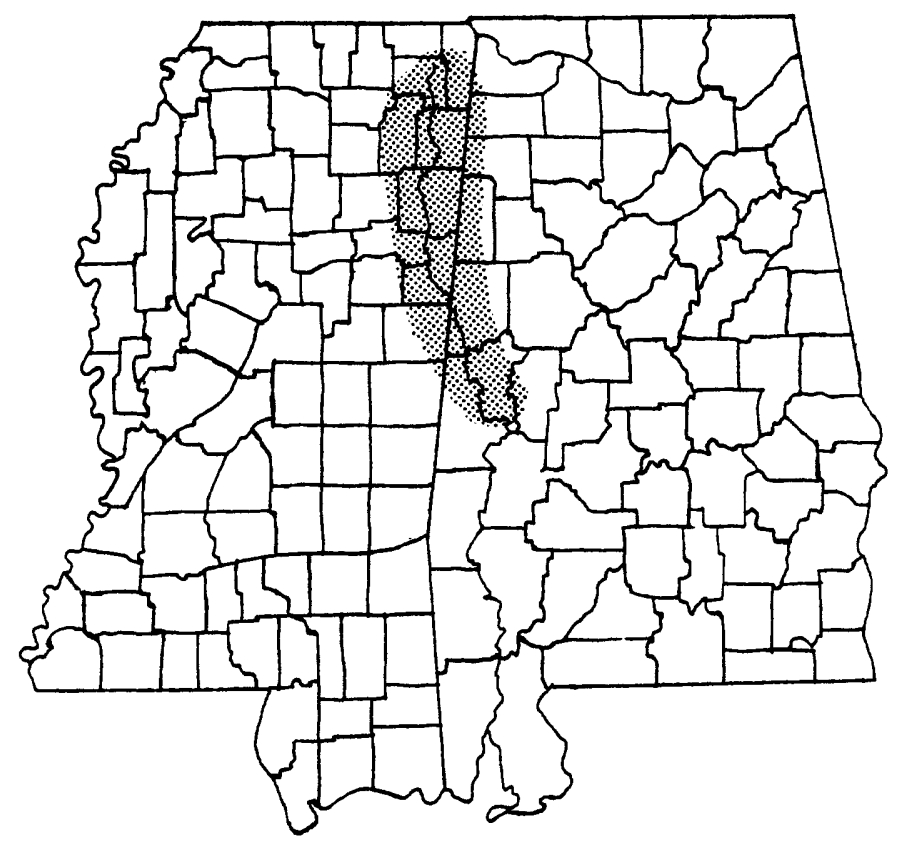

Location of study on

Tennessee-Tombigbee Waterway 


\section{POTENTIOMETRIC MAPPING}

Water-level data are necessary for the determination of the potentiometric surface of the major aquifers in Mississippi. Potentiometric data provide valuable information for evaluating the State's ground-water resources. The Mississippi District potentiometric mapping project is conducted in cooperation with the Mississippi Office of Land and Water Resources and has the following objectives:

- Measure water-levels in wells completed in major aquifers in the State.

- Analyze water-level data to determine the potentiometric surface of each aquifer.

- Prepare potentiometric-surface maps and water-level-change maps for the major aquifers at alternating 5-year intervals.

During 1990, work was focused on aquifers underlying the northeastern quarter of the State including the Gordo, the Eutaw-McShan, and the Coffee Sand aquifers. Hydrologist Gala D.S. Goldsmith is the project chief of the potentiometric mapping project.

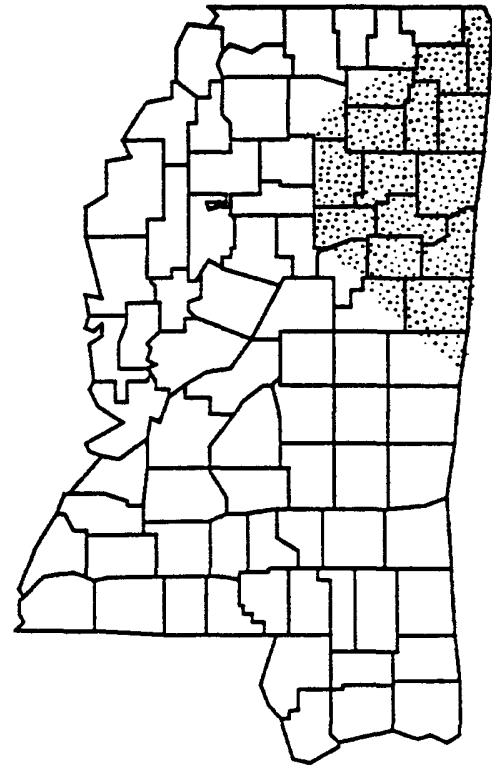

Gordo aquifer

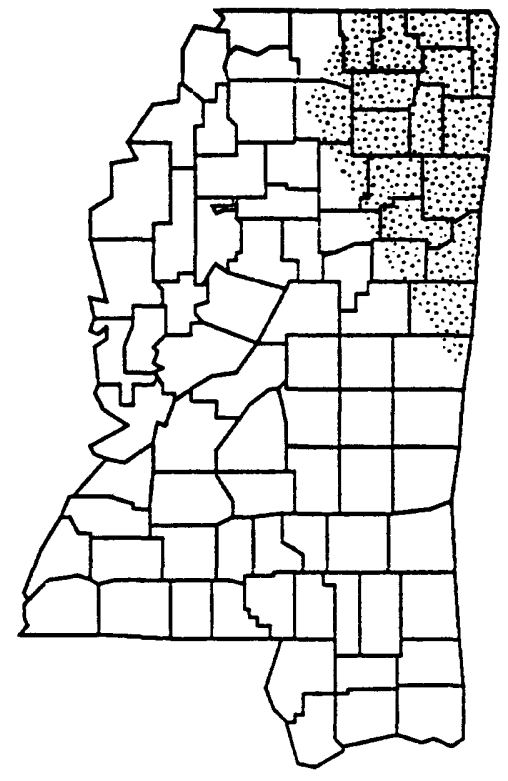

Eutaw-MCShan aquifer

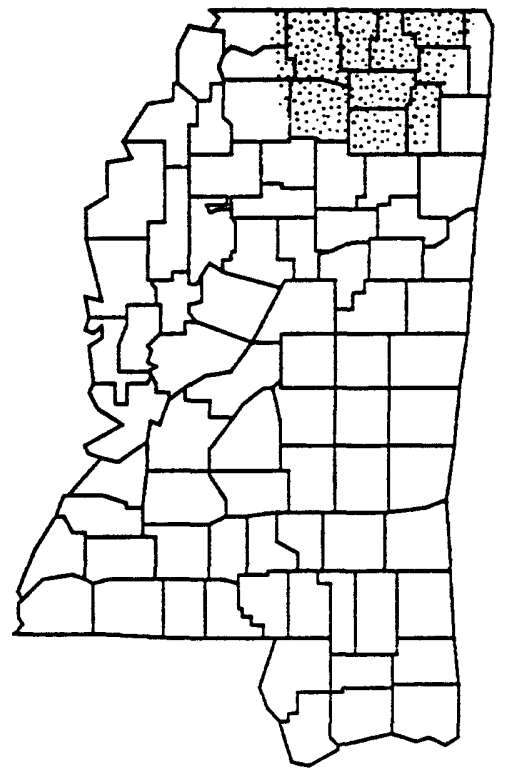

Coffee Sand aquifer

Areas of Active Potentiometric Mapping 


\section{LOW-FLOW CHARACTERISTICS OF MISSISSIPPI STREAMS}

Knowledge of the magnitude and frequency of low flows and flow-duration characteristics are important for water-supply planning, waste-load allocation, storage-facility design, and maintenance of quantity and quality of water for irrigation, recreation, and wildlife conservation. In Mississippi, planners and water managers must address issues involving the availability of streamflow for dilution and transport of waste effluent and the reliability and quality of surface water for supply. Although Mississippi is a water-rich State, receiving approximately 56 inches of rainfall statewide per year, the demand for surface water, particularly during the dry season when minimum streamflow occurs, can result in insufficient quantity and unacceptable quality for surface-water users. The objectives of a study to determine low-flow characteristics of Mississippi streams were :

- To initiate and extend low-flow data collection to small drainage areas.

- To analyze data to develop procedures for estimating low-flow characteristics of ungaged streams in Mississippi.

- To update previously published low-flow characteristics for gaged sites.

During 1990, analysis of data was completed and the report, "Low-flow and Flow-Duration Characteristics of Mississippi Streams," was completed and approved. A second report, which presents techniques for estimating low-flow characteristics for ungaged streamflow sites in Mississippi, is in review.

Pamela A. Telis directed the low-flow data-collection and analysis program in Mississippi.

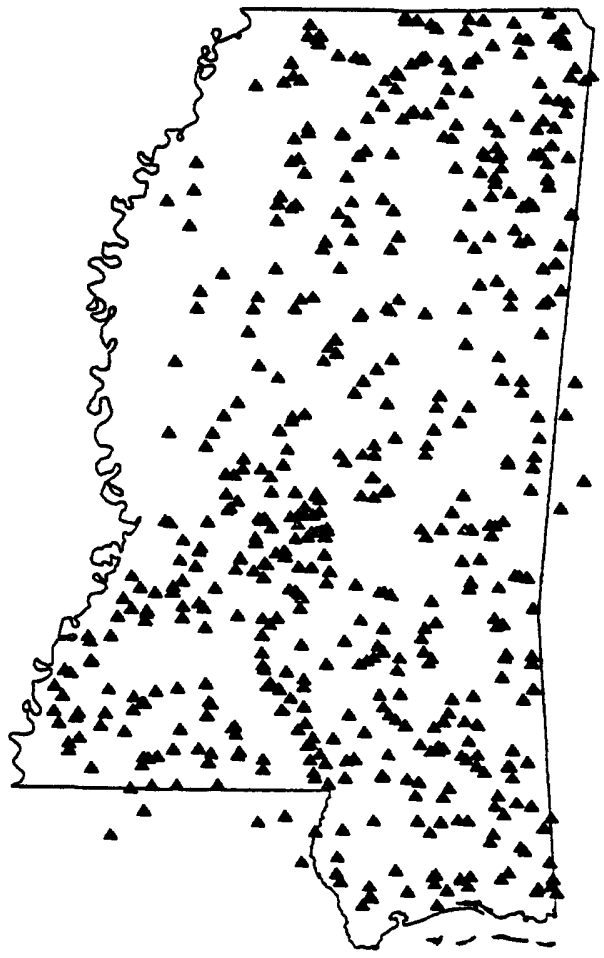

Locations of gaged low-flow sites 


\section{GROUND-WATER FLOW ANALYSIS OF THE COCKFIELD FORMATION AND THE SPARTA SAND IN THE THREE-COUNTY, JACKSON, MISSISSIPPI, METROPOLITAN AREA}

In 1990, about 25 million gallons per day of fresh ground water was pumped from the Cockfield Formation and the Sparta Sand aquifers in the Hinds, Madison, and Rankin County Jackson Metropolitan area. As a result of long-term pumping, significant cones of depression have developed in the potentiometric surfaces of the Cockfield and Sparta aquifers in this area. To gain an understanding of the groundwater flow system in the three-county area, the Mississippi District, in cooperation with the Mississippi Office of Land and Water Resources, is conducting a study of the Cockfield and Sparta aquifers. The study has the following objectives:

- Assemble data to define the hydrogeologic framework of the ground-water flow system underlying the three-county area.

- Develop a three-dimensional digital model representing the flow system underlying the area.

- Analyze the ground-water flow system using model results to estimate the response of the flow system to present and future pumping.

- Investigate the effects of various water-resource management decisions and ground-water pumping scenarios on the groundwater flow system underlying the three-county area.

During fiscal year 1991, the project work will be focused on developing and calibrating the ground-water flow model. Model results will be presented in a U.S. Geological Survey Water-Resources Investigations Report.

Hydrologist J. Kerry Arthur is the principal investigator for the study.

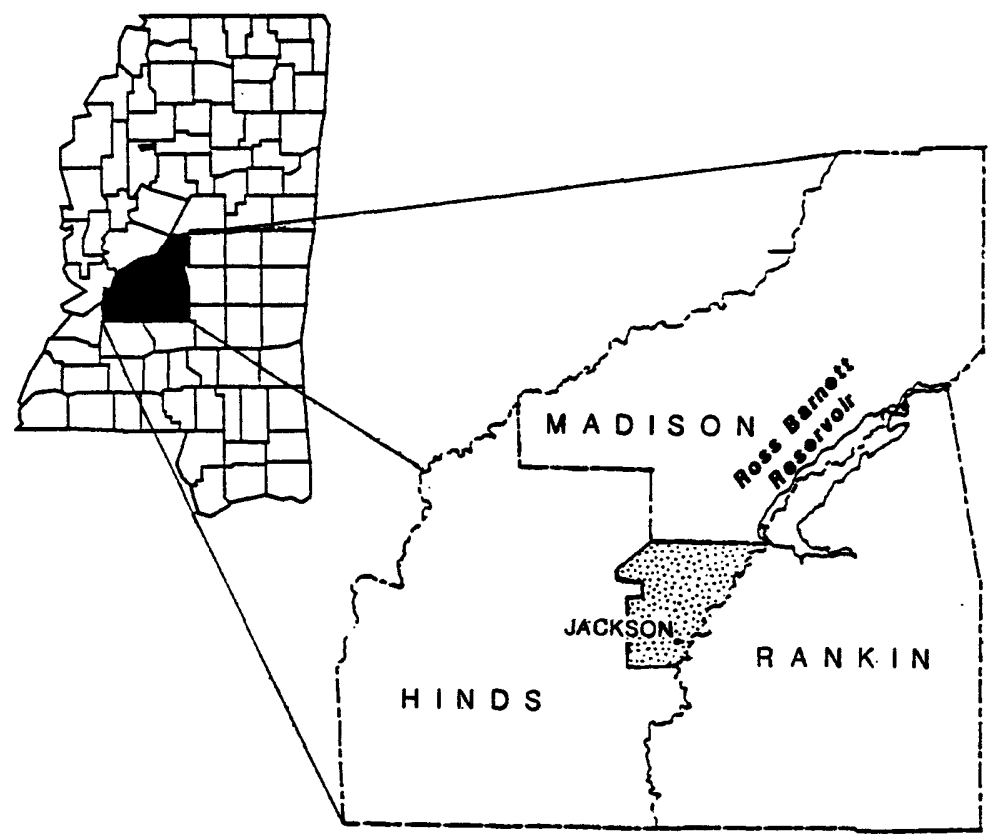

Study Area 


\section{MAGNITUDE AND FREQUENCY OF FLOODS IN MISSISSIPPI}

The magnitude and frequency of floods are key factors in the design of bridges, highway embankments, culverts, levees, dams, and other structures near streams. Effective flood-plain management and the determination of flood insurance rates require information on the magnitude and frequency of floods. In 1987, the Mississippi District, in cooperation with the Mississippi State Highway Department, began a study to update previous flood-frequency reports. The objectives of this project are to:

- Develop regional methods for estimating the magnitude and frequency of floods for Mississippi streams having recurrence intervals ranging from 2- to 500 -years.

- Document flood data and flood frequencies at streamflowgaging stations in Mississippi.

During 1990, final analyses were completed and final reports were in preparation. Mark N. Landers served as project chief prior to his transfer in May 1990. K. Van Wilson, Jr. is currently project chief of this study.

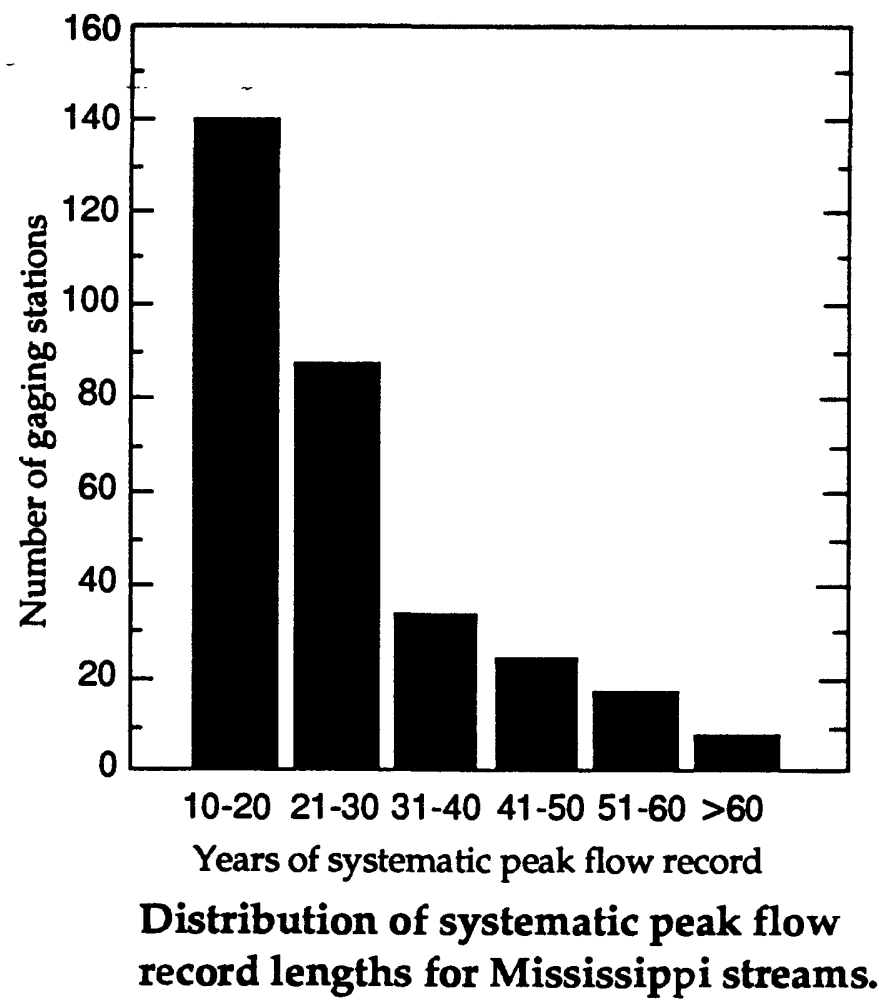




\section{ANALYSIS OF AQUIFER-TEST DATA}

For State agencies to manage and receive maximum benefit from Mississippi's ground-water resource, it is essential that hydrologists, water-well contractors, water users, and water-resources planners and managers have information that describes hydraulic characteristics of the principal aquifers in the State. Such information commonly is obtained from aquifer tests. The U.S. Geological Survey, in cooperation with State, local, and other Federal agencies, has been gathering and analyzing aquifer-test data in Mississippi since the 1940's.

During 1990 and 1991, in cooperation with the Mississippi Office of Geology, the Mississippi District prepared a report that compiles and summarizes the results of 574 aquifer tests in the State for which the data have been analyzed by the USGS. The report, Water-Resources Investigations Report 90-4155, "Summary of Aquifer Tests in Mississippi, June 1942 through May 1988," was the first published since 1971 for aquifer-test data in Mississippi.

Hydrologists Daphne Darden and Larry J. Slack are the principal investigators for the Mississippi aquifer-test program. The Mississippi District continues to receive aquifer-test information for the State provided by water-well drillers, State and local agencies, and other Federal agencies.

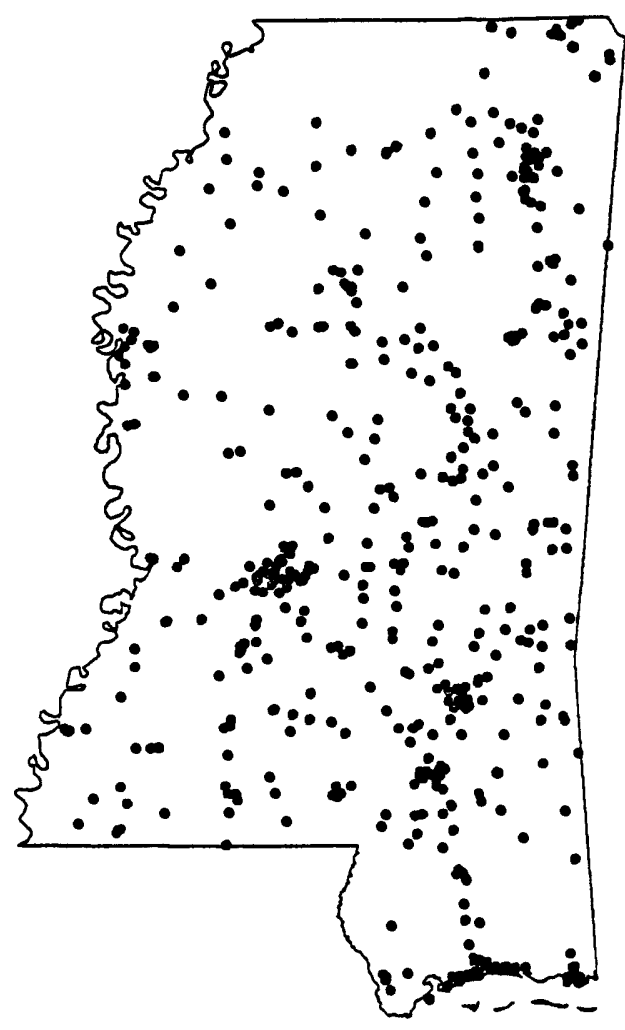

Locations of aquifer tests 


\section{CHANNEL ADJUSTMENT PROCESSES, BANK-SLOPE DEVELOPMENT, AND LONG-TERM CHANNEL GEOMETRY IN SELECTED REACHES OF MISSISSIPPI STREAMS}

Modifications to streams in Mississippi can result in unstable channels. When unstable gradients and bank conditions are imposed on a stream, the channel undergoes natural adjustments until more stable conditions exist. Channels in some Mississippi streams have widened more than three times their pre-modified width and have degraded as much as 19 feet as the result of channel modifications. Channel adjustment downstream from dams and along modified stream reaches can cause property loss and loss of wetlands. Channel modifications have contributed to bridge failure in some instances. Assessment and prediction of channel morphology are needed to adequately protect existing bridges and culverts and to aid in the design of proposed structures. In 1987, the Mississippi District, in cooperation with the Mississippi State Highway Department, began a quantitative study using documented techniques to estimate near-future channel-adjustment processes. The major objectives are:

- Identify channel instability.

- Estimate the amounts of near-future channel-bed degradation or aggradation and channel bank-widening or accretion.

- Describe the expected stable channel geometry at sites undergoing channel adjustment.

To date, nine sites have been analyzed and results have been published for five of these sites. Hydrologist K. Van Wilson, Jr. is the project chief for this study.
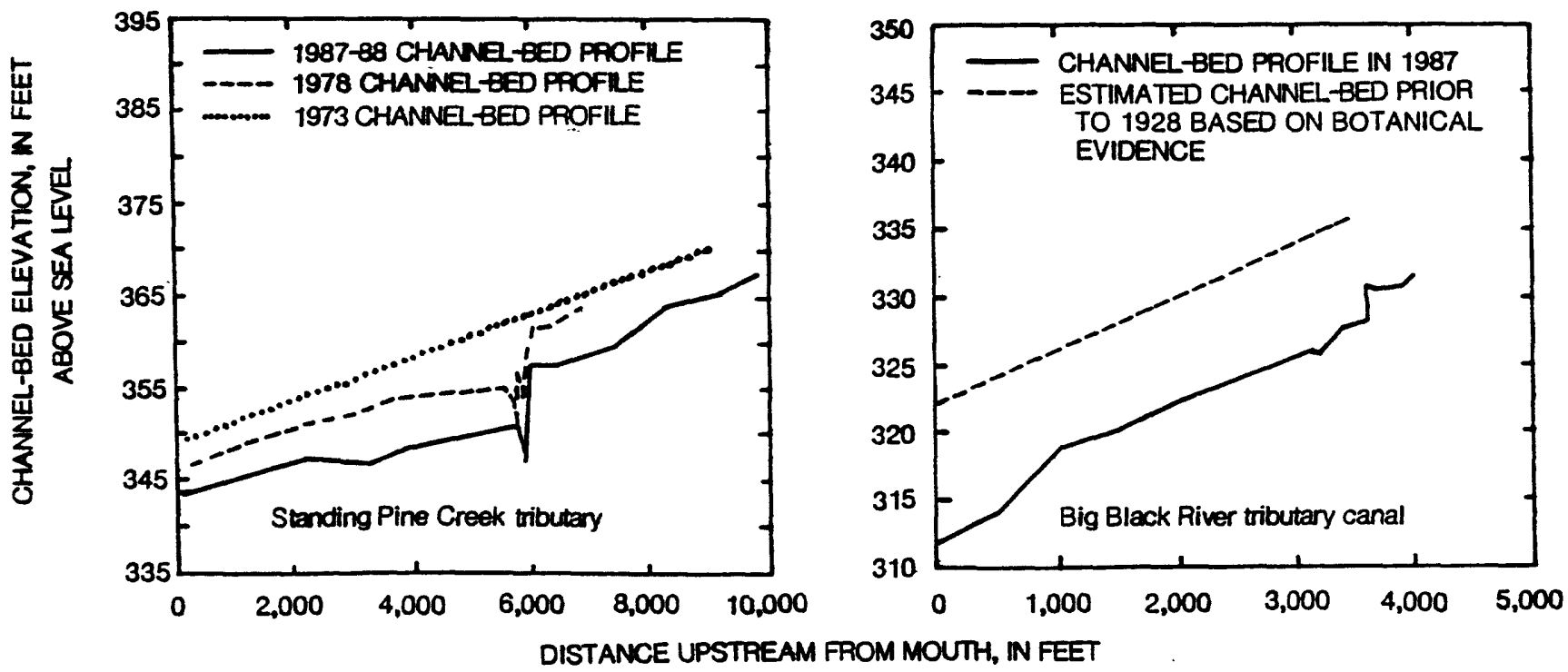

Examples of channel-bed degradation 


\section{GROUND-WATER RESOURCES OF \\ NORTHEASTERN MISSISSIPPI}

The Tuscaloosa aquifer system contains freshwater in an area of about 9,000 square miles in northeastern Mississippi. This aquifer system is the primary source of ground-water for public and industrial water supplies in about three-fourths of this area. Increased pumpage for public, industrial, and military uses during and since World War II has greatly intensified the draft on the aquifer system. Local overdevelopment of the aquifer has resulted in large declines in ground-water levels and attendant supply problems. Less intense but more extensive water-level declines of about 2 feet per year have occurred throughout large parts of the area. The need for additional water supplies to support continuing industrial growth in the area is expected to exacerbate these problems in the future.

The principal objective of this study, which is being conducted in cooperation with the Mississippi Office of Land and Water Resources and the Tombigbee River Valley Water Management District, is to describe and quantify the Tuscaloosa aquifer system in the area using a three-dimensional model of the system. In particular, the model will be used to investigate the probable response of the system to present and anticipated future pumping and to investigate the consequences of various management programs.

During 1990, work focused on characterization of geometric and hydrologic properties of the Tuscaloosa aquifer system in the study area from analysis of available well logs, aquifer tests, and other data.

Hydrologist Michael J. Mallory is the principal investigator for this project.

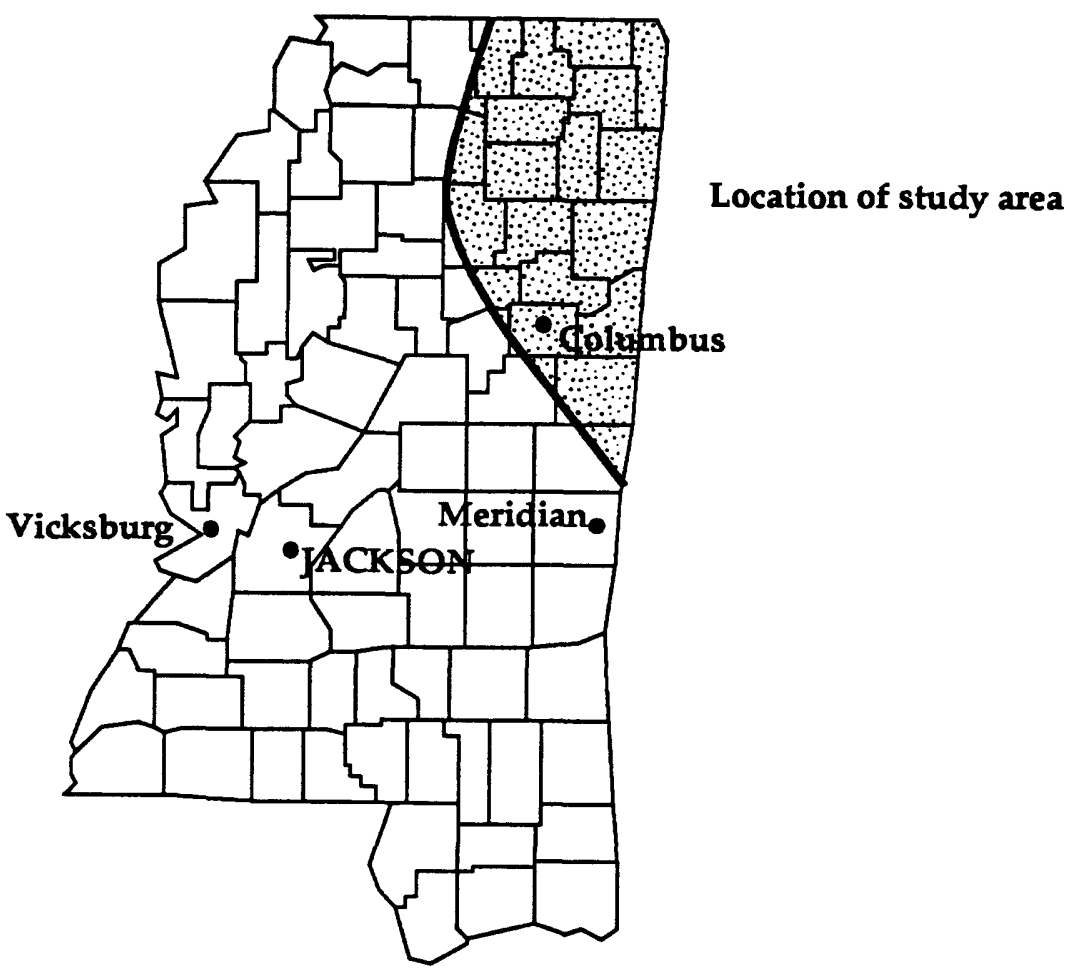




\section{GEOHYDROLOGY AND SIMULATED EFFECTS OF GROUND- WATER WITHDRAWALS ON THE MIOCENE AQUIFER IN SELECTED AREAS OF SOUTHERN MISSISSIPPI}

Local overdevelopment of ground water from the Miocene aquifer has led to ground-water-level declines and water-supply problems in several areas in southern Mississippi. Although the aquifer is capable of supplying the current demand, significant increases in ground-water withdrawals will require careful management of the ground-water resources. The areas of concern include the Laurel-Hattiesburg area in Jones and Forrest Counties, the Natchez area in Adams County, and the Mendenhall area in Simpson County; an additional area of study includes the Miocene-age sediments in Pike County. The Mississippi District is conducting a comprehensive investigation of the ground-water resources in these areas in cooperation with the Mississippi Office of Land and Water Resources, the Pearl River Basin Development District, and the Pat Harrison Waterway District. The objectives of this investigation are to:

- Develop three-dimensional ground-water models of the Miocene aquifer in selected areas (Laurel-Hattiesburg, Natchez, and Mendenhall).

- Investigate probable response of the aquifer to present and future pumping.

- Investigate consequences of various management and pumping schemes and stresses as compared with existing or expected patterns.

During 1990, literature and file data searches began. Well logs were analyzed and a cross section was prepared for the Miocene-age sediments in Pike County, and well-log analysis was begun for the Laurel-Hattiesburg area. Waterlevel measurements will be made in the Laurel-Hattiesburg area to assist in calibrating the first model. Preliminary modeling of the Laurel-Hattiesburg area will begin during 1991.

Hydrologist Nancy L. Barber is the project chief for the Miocene aquifer ground-water modeling project.

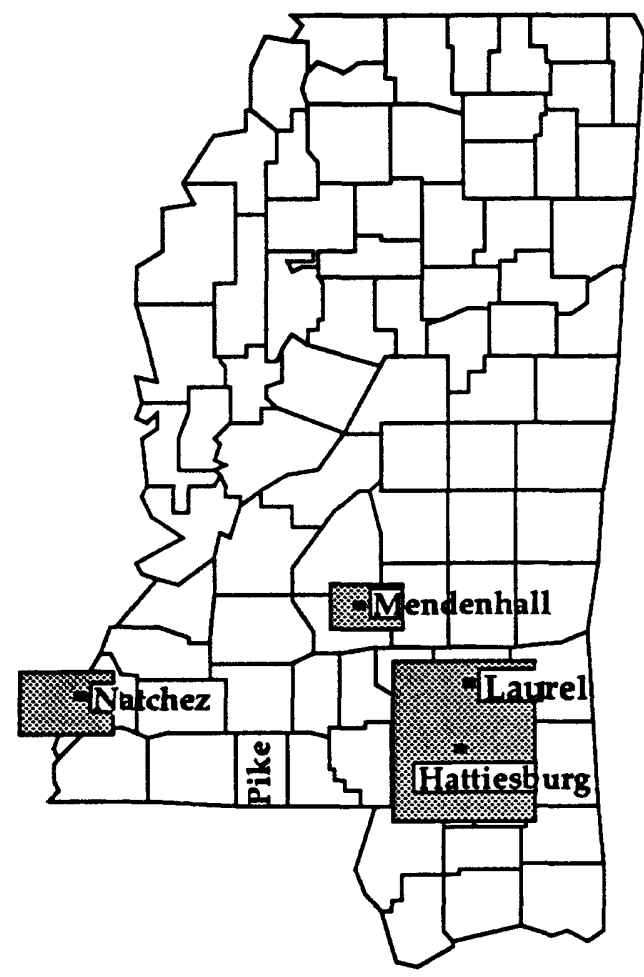




\section{BRIDGE-SCOUR PREDICTION EQUATIONS FOR MISSISSIPPI STREAMS}

Scour around bridges presents a problem of vital importance in constructing bridges spanning waterways. The erosive action of flowing water may expose or undermine bridge pier and bridge abutment foundations, which can induce structural failure. Therefore, accurate estimates of potential scour are essential in the design, construction, and maintenance of bridges. In 1990, the Mississippi District, in cooperation with the Mississippi State Highway Department, began a 4-year study with the following objectives:

- Collect bridge-scour data during floods using various scour monitoring techniques.

- Evaluate bridge-scour prediction equations currently being used in bridge design.

- Develop improved bridge-scour prediction equations if sufficient data are available.

During 1990, 21 bridge sites were chosen for potential data collection, scour data were collected (before, during, and after each significant flood) at 15 of these sites, and data analysis began.

K. Van Wilson, Jr. is the project chief for this study.

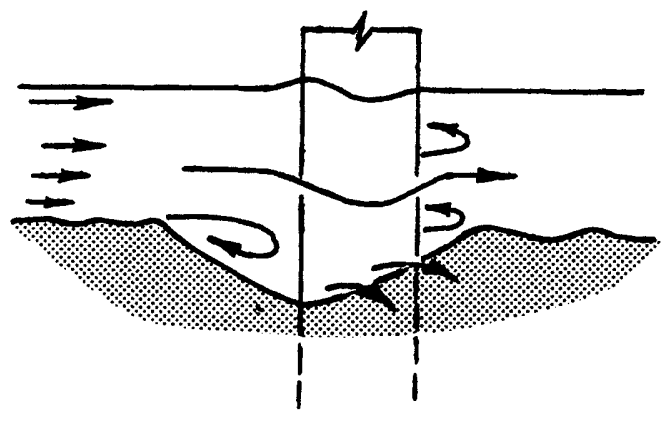

Local scour at a pier

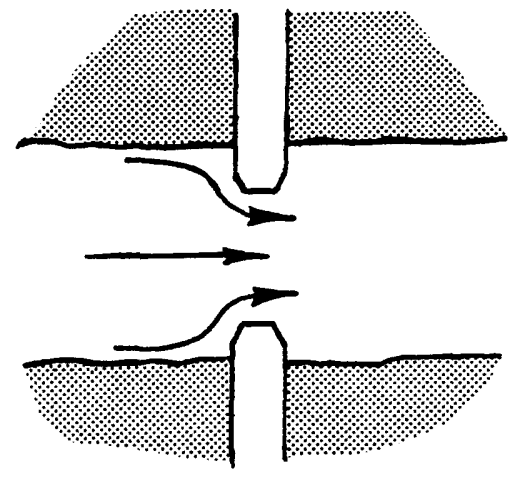

Scour at a projecting abutment

Scour associated with bridge piers and abutments in path of flow (Modified from Culbertson, D.M., Young, LE., and Brice, J.C., 1967, Scour and fill in alluvial channels with particular reference to bridge sites: U.S. Ceological Suroey open-file report, $58 \mathrm{pJ}$ 


\section{DEVELOPMENT OF A METHODOLOGY TO BETTER ESTIMATE CHANNEL MEANDERING}

Rivers are one of the most dynamic of all geomorphic forms. Lateral erosion problems caused by river meandering result in loss of arable land, bridge failure, and endangerment of human life. An estimation of the course of channel meandering is important in the hydraulic design of bridges. In 1990, the Mississippi District initiated a study in cooperation with the Mississippi State Highway Department to develop a better methodology for defining and estimating channel meandering using streamflow data, channel-bank soil strength data, historical aerial photography, and a geographic information system. Specific objectives of the project are to:

- Map and define past rates and direction of meandering at selected sites in Mississippi.

- Mathematically simulate the identified past channel meandering.

- Develop a procedure for estimating future channel meandering.

In 1990, the Mississippi District and the Mississippi State Highway Department identified 17 potential study sites. Equipment needed for photointerpretation, map transfer, and field work was purchased. Aerial photography imaged in the 1930's was obtained from the National Archives; soils data for nine of the sites were obtained from the Mississippi State Highway Department. Field work (such as determining channel geometry and stream profiles) was accomplished at six sites and mapping of aerial photography was begun. Phil Turnipseed serves as the project chief for this study.

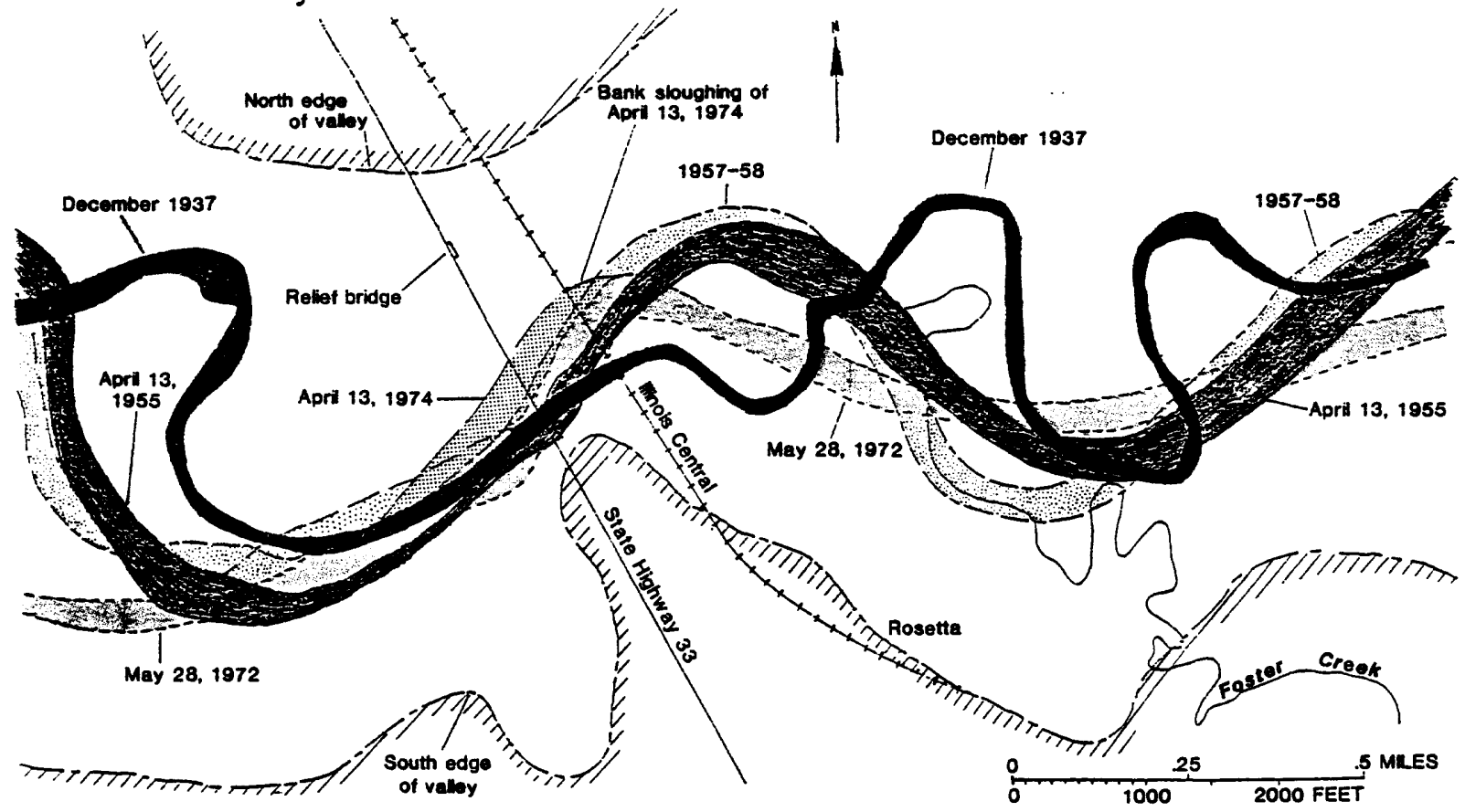

Channel changes in Homochitto River at State Highway 33, Rosetta, Mississippi (Modified from K.V. Wilson, Sr., 1979, Changes in channel characteristics of the Homochitto River and tributaries, Mississippi: U.S. Geological Suroey Open-File Report 79-554, 18 p.) 


\section{SUSCEPTIBILIITY OF MAJOR AQUIFERS IN MISSISSIPPI TO SURFACE AND SHALLOW-SOURCE CONTAMINATION}

The U.S. Geological Survey, Mississippi District, in cooperation with the Mississippi Office of Pollution Control and the Mississippi Department of Agriculture and Commerce, is conducting an investigation to describe the relative susceptibility of major aquifers in Mississippi to surface and shallow-source contamination. A geographic information system will be used to integrate and analyze data describing the various geologic, hydrologic, and physiographic features that influence aquifer susceptibility to these types of contamination.

The objectives of this project are to:

- Define and delineate geologic, hydrologic, and physiographic features that influence aquifer susceptibility to surface and shallow-source contamination.

- Evaluate the relative susceptibility of the major aquifers in Mississippi to surface and shallow-source contamination.

The project is statewide in scope and evaluations will be done on 14 multicounty study areas. The first susceptibility evaluations will focus on study areas located in the Delta. The project chief is hydrologist Richard S. Moreland.

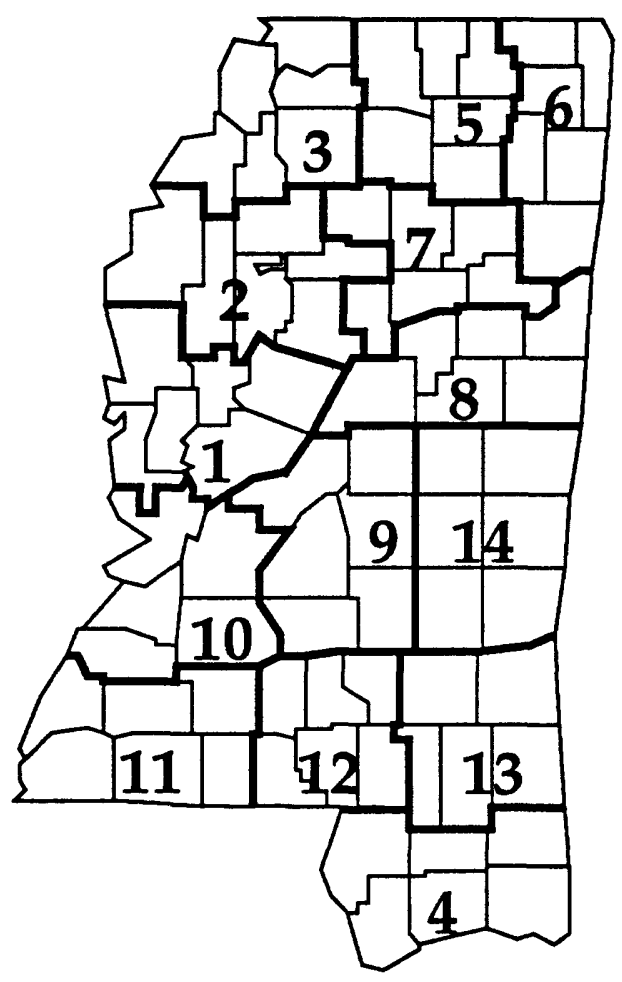

Multi-county study areas 


\section{DETERMINATION OF METHODS \\ FOR CHARACTERIZATION OF UNDERGROUND \\ INJECTION SITES IN MISSISSIPPI}

Underground injection is an alternative technique used by many industries for disposal of, primarily, liquid wastes. This technique involves injecting wastewater into confined areas underground that have little or no potential for contamination of water supplies. This technique could pose a threat to water supplies if the waste migrates out of the confining geologic strata. Data describing the geohydrologic conditions in the injection zones often are limited because these zones are far below aquifers penetrated by water-supply wells. Therefore, the need exists for more information on which to base management decisions concerning underground injection and potential site contamination.

The Mississippi District is working in cooperation with the Mississippi Office of Pollution Control for the next 2 to 4 years to provide information necessary for gaining understanding of the complex processes involved in underground injection. Currently, Mississippi has several underground waste-disposal injection sites.

During the first year, a literature search will be conducted to identify:

- The mechanisms involved in wastewater injection in Mississippi.

- The theory on which the installation and maintenance of injection wells is based.

- The methods used in locating and monitoring injection sites.

During the second year of the project, a preliminary analysis will be completed for the purpose of determining the best methodology to characterize injection wells in Mississippi. At that time, the Mississippi District and the Mississippi Office of Pollution Control will jointly determine if existing characterizations of injection sites operating in Mississippi need updating. If site characterizations need updating, the project will continue. Results of the study will be presented in a Water-Resources Investigations Report at the conclusion of the study.

Hydrologists Michael J. Mallory and Richard A. Rebich

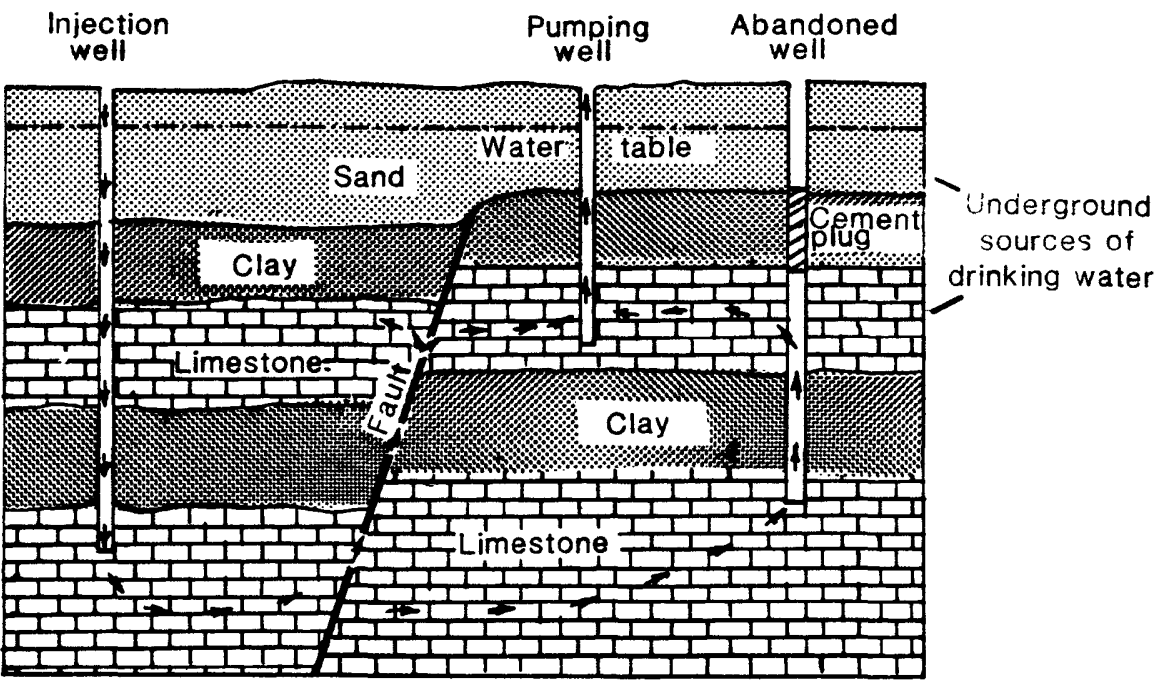

Examples of liquid waste movement from deep subsurface injection site to shallow aquifer used for public supply (Modified from Hickey, J.J., and Vecchioli, John, 1986, Subsurface injection of liquid waste with emphasis on injection practices in Florida: U.S. Geological Suroey Water-Supply Paper 2281) are the principal investigators for this project. 


\section{MISSISSIPPI DISTRICT REPORTS PUBLISHED SINCE 1989}

Arthur, J.K., and Taylor, R.E., 1990, Definition of the geohydrologic framework and preliminary simulation of ground-water flow in the Mississippi embayment aquifer system, Gulf Coastal Plain, United States: U.S. Geological Survey Water-Resources Investigations Report 86-4364, 97 p.

Barber, N.L., 1991, Water withdrawals in the Black Warrior-Tombigbee basin and Alcorn County, Mississippi, 1985-87: U.S. Geological Survey Water-Resources Investigations Report 90-4061, $42 \mathrm{p}$.

Bednar, G.A., and Grantham, P.E., 1989, Precipitation-quality monitoring in southern Mississippi, 1982-87: U.S. Geological Survey Open-File Report 89-266, 31 p.

Callahan, J.A., and Barber, N.L., 1989, Water-use data collection program in Mississippi, in Proceedings of the Mississippi Water Resources Conference, 1989: Water Resources Research Institute, Mississippi State, Miss., p. 53-57.

Callahan, J.A., and Barber, N.L., 1990, Freshwater use in Mississippi, 1985: U.S. Geological Survey Water-Resources Investigations Report 88-4229, 1 sheet.

Goldsmith, G.D.S., 1990, Potentiometric-surface map of the Gordo aquifer in northeastern Mississippi, August through December 1987: U.S. Geological Survey Water-Resources Investigations Report 89-4060, 1 sheet.

Goldsmith, G.D.S., 1991, Potentiometric-surface map of the Eutaw-McShan aquifer in northeastern Mississippi, August through December 1987: U.S. Geological Survey Water-Resources Investigations Report 90-4157, 1 sheet.

Landers, M.N., 1989, Regional skew coefficients for flood-frequency analysis of Mississippi streams, in Proceedings of the Mississippi Water Resources Conference, 1989: Water Resources Research Institute, Mississippi State, Miss., p. 66-70.

Mallory, M.J., 1990, Computer methods for evaluating wellhead protection areas in Proceedings of the Mississippi Water Resources Conference, 1990: Mississippi Water Resources Research Institute, Mississippi State, Miss., p. 127-135.

Mallory, M.J., 1990, Evaluation of three scenarios of ground-water withdrawal from the Mississippi River alluvial aquifer in northwestern Mississippi: U.S. Geological Survey Open-File Report 90-103, 17 p.

Morris, Fred, III, 1988, Hydrologic monitoring in the area of the TennesseeTombigbee Waterway, Mississippi-Alabama, Fiscal Year 1986: U.S. Geological Survey Open-File Report 88-321, 520 p. 
Rebich, R.A., and Landers, M.N., 1990, Upstream extent of saline water in the Pascagoula River, in Proceedings of the Mississippi Water Resources Conference, 1990: Mississippi Water Resources Research Institute, Mississippi State, Miss., p. 98-104.

Slack, L.J., and Darden, Daphne, 1991, Summary of aquifer tests in Mississippi, June 1942 through May 1988: U.S. Geological Survey Water-Resources Investigations Report 90-4155, 40 p.

Slack, L.J., and Oakley, W.T., 1989, Tritium analyses of shallow ground water in Mississippi, April 1989: U.S. Geological Survey Open-File Report 89-418, 8 p.

Slack, L.J., and Oakley, W.T., 1991, Tritium in ground water in Mississippi, 1989-90:

U.S. Geological Survey Open-File Report 91-177, 12 p.

Southard, R.E., 1989, Mean annual runoff in the East Gulf Coastal Plain of Mississippi, 1939-85: U.S. Geological Survey Water-Resources Investigations Report 88-4079, 1 sheet.

Taylor, R.E., and Arthur, J.K., 1989 [1990], Hydrogeology of the middle Wilcox aquifer system in Mississippi: U.S. Geological Survey Water-Resources Investigations Report 89-4036, 2 shcets.

Telis, P.A., 1990, Improving estimates of low-flow characteristics for streamflow stations affected by climatic cycles, in Proceeding of the Mississippi Water Resources Conference, 1990: Water Resources Research Institute, Mississippi State, Miss., p. 37-40.

Telis, P.A., 1991, Low-flow and flow-duration characteristics of Mississippi streams: U.S. Geological Survey Water-Resources Investigations Report 90-4087, 214 p.

Turnipseed, D.P., and Wilson, K.V., Jr., 1989, Channel and bank stability of Sand Branch tributary at State Highway 342 near Pontotoc, Pontotoc County, Mississippi: U.S. Geological Survey Water-Resources Investigations Report 89$241,15 \mathrm{p}$.

Turnipseed, D.P., and Wilson, K.V., Jr., 1990, Channel and bank stability of Twentymile Creek at U.S. Highway 45 near Wheeler, Prentiss County, Mississippi: U.S. Geological Survey Open-File Report 90-111, 16 p.

Wilson, K.V., Jr., and Turnipseed, D.P., 1989, Channel stability of selected streams in northern Mississippi, in Proceedings of the Mississippi Water Resources Conference, 1989: Water Resources Research Institute, Mississippi State, Miss., p. 104-112.

Wilson, K.V., Jr., and Turnipseed, D.P., 1989, Channel and bank stability of Osborne Creek at U.S. Highway 45 near Wheeler, Prentiss County, Mississippi: U.S. Geological Survey Open-File Report 89-581, 13 p. 
Wilson, K.V., Jr., and Turnipseed, D.P., 1989, Channel and bank stability of Big Black River Cannel tributary at U.S. Highway 82 at Stewart, Montgomery County, Mississippi: U.S. Geological Survey Open-File Report 89-35, 16 p.

Wilson, K.V., Jr., and Turnipseed, D.P., 1990, Channel and bank stability of Wolf Creek and a tributary at U.S. Highway 45 near Wheeler, Prentiss County, Mississippi: U.S. Geological Survey Open-File Report 90-110, 18 p. 